\title{
Business Registration Reform Case Studies
}

\section{Ireland}

Dobromir Christow, Investment Climate Advisory Services, World Bank Group John Olaisen, Norway Registers Development AS

June 2009

Investment Climate Advisory Services

World Bank Group 


\section{About the Investment Climate Advisory Services of the World Bank Group}

The Investment Climate Advisory Services of the World Bank Group helps governments of developing and transition countries improve and simplify business regulations, attract and retain investments, helping clients foster growth and create jobs. It is funded by three World Bank Group members - the International Finance Corporation (IFC), the Multilateral Investment Guarantee Agency (MIGA), and the World Bank-and by several donor partners who collaborate with us through the multi-donor FIAS platform.

The findings, interpretations and conclusions included in this note are those of the author and do not necessarily reflect the view of the Executive Directors of the World Bank Group or the governments they represent. 


\section{Table of Contents}

$\begin{array}{ll}\text { Introduction } & 4\end{array}$

Methodology $\quad 5$

Results of the Reforms 5

$\begin{array}{ll}\text { Lessons from the Case Studies } & 6\end{array}$

Summary and Key Characteristics of the Reform 8

$\begin{array}{ll}\text { A. Background } & \mathbf{1 0}\end{array}$

A.1. Legal Framework and EU Membership 10

$\begin{array}{ll}\text { A.2. Institutional Framework } & 10\end{array}$

A.3. Business Registration Procedures before the Reform 11

$\begin{array}{ll}\text { B. Reform Planning } & 11\end{array}$

$\begin{array}{ll}\text { B.1. Mandate } & 11\end{array}$

B.2. Organization and M\&E of Reform 12

$\begin{array}{lr}\text { C. Reform Dimensions } & 14\end{array}$

$\begin{array}{ll}\text { C.1. Legislative Reform } & 14\end{array}$

C.1.1. Amendments in Companies Legislation $\quad 14$

C.1.2 Introduction of Electronic Documents and Signature $\quad 15$

C.1.3. New Enforcement Regime, Penalty and Sanctions System 16

C.1.4. ICT Applications in the Penalty and Sanctions System 16

C.2. Institutional Framework after the Reform 16

C.3. Business Registration Process and Procedures after the Reform 18

$\begin{array}{ll}\text { C.4. E-filing Services after the Reform } & 19\end{array}$

C.5. Funding, Costs, and Donor Support 20

C.6. Information Campaign 20

D. Conclusion and Results achieved through Reform 21

D.1. Impact and Performance Indicators $\quad 21$

$\begin{array}{ll}\text { D.2. Conclusion } & 21\end{array}$

Annex 1. Key CRO Personnel $\quad 23$

Annex 2. Reform Workflow 24 


$\begin{array}{ll}\text { Abbreviations } & \\ \text { CLRG } & \text { Companies Law Review Group } \\ \text { CORE } & \text { Companies Online Registration Environment } \\ \text { CRO } & \text { Companies Registration Office } \\ \text { CrXML } & \text { company registration Extensible Markup Language } \\ \text { DETE } & \text { Department of Enterprise, Trade and Employment } \\ \text { EDI } & \text { Electronic Data Interchange } \\ \text { EC } & \text { European Community } \\ \text { EU } & \text { European Union } \\ \text { FINER } & \text { Framework for Internet-based registration and filing } \\ \text { FTP } & \text { File Transfer Protocol } \\ \text { HTTP } & \text { Hypertext Transport Protocol } \\ \text { ICT } & \text { information communications technology } \\ \text { ID } & \text { Digital identification number } \\ \text { IEE } & \text { Integrated Enforcement Environment } \\ \text { IT } & \text { information technology } \\ \text { ROC } & \text { Registrar of Companies, manager of the CRO } \\ \text { RSS } & \text { Registration Service System } \\ \text { UK } & \text { United Kingdom } \\ \text { XML } & \text { Extensible Markup Language }\end{array}$




\section{Introduction}

Over the last twenty years, a number of countries have recognized the importance of smooth and efficient business start up procedures. A functioning business registration system is now viewed as an important regulatory requirement of any economy, and a predictable, transparent, and modern business registration system is acknowledged to help promote private sector growth and job generation.

Increasingly, governments around the world have undertaken efforts to streamline their business registration systems in order to gain whatever advantage they could in creating growth and jobs. Representatives among developed nations, countries in transition, and developing countries have explored and implemented varied approaches to transforming their business registration regulatory requirements.

While the approaches have varied, the foundation of all business registration reform is redesigning the legal and institutional regulatory framework that underlies the business registration process. Stable and professional business registration institutions help establish standards of trust, transparency, and predictability, and ensure that the public is informed of the facts as quickly as possible.

Tools that have been employed to implement reforms also have not been uniform. Some governments have created one-stop shops, while others have not; some have introduced technology and modern management techniques, while others have relied on traditional methods; some have empowered registration bodies to focus on service, while others have imposed penalty regimes on delinquent companies. Practice shows that in order to achieve sustainable reform, the menu of specific changes is not nearly as important the overall goals of reform. Countries who have achieved more business friendly environments and, consequently, larger formal private sectors following implementation of reforms, all set out to simplify the system and remove burdens on companies while focusing on protecting third parties by maintaining accuracy and encouraging compliance.

Business registration gives businesses formal status and formal operation in the marketplace. It is a dynamic process that impacts the life of its stakeholders, commercial counterparties, and employees by introducing new responsibilities, opportunities, and challenges. 


\section{Methodology}

This collection of case studies describes experiences and draws lessons from varied business registration reform programs in economies in vastly different stages of development: Bulgaria, Estonia, Ireland, Madagascar, and Malaysia. The case studies were written based on a desk study of reforms in each country discussed. Then, more detailed information was gathered by field-based researchers. In some cases, detail on the business registration process that was in place prior to implementation of reforms was unavailable. As such, data on the number of businesses registered and the time required to completed registration before and after the reforms cannot be compared and contrasted.

Not all of the stories are of comprehensive reform programs that were widely successful. Most countries took different approaches to implementing the reforms. In fact, one of this paper's most important findings is that reforms of business registration processes can be implemented in a variety of legal, institutional, and cultural settings, and while most countries share common desired reform outcomes, there is no single model for achieving these results.

Whatever their range of success, all of the reforms discussed in these case studies sought to improve the instruments, processes, and institutions underlying all forms of business registration and related services. In all five countries, the broad goals of reforms were to increase economic growth and bring as many businesses as possible into the formal sector. Given the varied nature of the countries, the reform programs focused on achieving different aspects of the desired outcomes-simplified and reduced numbers of procedures, reduced costs, increased availability and transparency of information, increased compliance rates, increased protection of third parties.

\section{Results of the Reforms}

Bulgaria: Prior to reforms, business registration was handled in the 28 district courts. While a registration agency was created to take over business registration, the reform process was only partially successful due to problems in four areas: lack of strong legislative will, insufficient financial support by the government, inappropriate organizational structure of the new business registration agency, and weak human resource management.

Estonia: The government-led initiative to reform business registration introduced an experimental approach to e-registration. However, this approach achieved real reductions in the time required to register businesses only after the Minister of Justice set a requirement that business registration be completed in two hours. The actual time required was one day, but in addition to the time savings, the reforms led to a 130 percent increases in the number of enterprises registered from 1998 to 2008. 
Ireland: During the economy's high-growth period of 1980s and 1990s, a low rate of company compliance with the annual return obligations contributed to a large backlog in registry updates. Although Parliament discussed this problem on numerous occasions over these two decades, improvements occurred only following a direct initiative from the Prime Minster in 1999 to introduce an enforcement and penalty regime. Perhaps in part due to the fact that the registry in Ireland is not legally binding, companies saw little incentive to change their behavior prior to the introduction of penalties for failure to update the registry. However, as of 2008, compliance with filing annual returns is above 90 percent and still improving.

Madagascar: While the donor-initiated reform program led to the establishment of a one-stop shop for business registration failed to achieve any recognizable improvements of the business registration process and services, the President's instruction to create the Economic Development Board of Madagascar (EDBM) resulted in significant simplification of registration requirements and procedures. When the EDBM began managing one-stop-shop procedures, registration of companies in Antananarivo was able to be completed in one step and within 5-7 days. This led to a 158 percent increase in the number of new businesses registered from 1998 to 2007.

Malaysia: The Cabinet established the Companies Commission of Malaysia in order to facilitate growth of the private sector economy. The top-down supported reform was implemented by this autonomous agency that adopted a service orientation and utilized IT and modern management tools to improve performance while the steps in the process of business registration remained unchanged. Through the electronic system, registration time dropped to one day, and the number of new enterprises registered increased by 58 percent from 2001 to 2008.

\section{Lessons from the Case Studies}

Despite lack of similarity among the case studies, some themes emerge as important lessons about business registration reform.

1. Top-level support improves results. Results are most likely to be achieved if they are supported by and even led from the highest levels of government. This is particularly true if the reforms are occurring in a tumultuous or high-growth period for the country.

\section{Legal concept and principles matter.}


- Legally valid business registries are most likely to be kept up-to-date by companies and therefore also provide third parties who access the information the best protection from inaccuracies.

- Simplification of pre-registration procedures, such as notarization requirements and publishing business registration publicly for a period of time have substantial impact on the time and costs of starting of a business.

\section{Technology leads to efficiency.}

- The use of information technology can facilitate the simplification of registration procedures and consolidation of steps in the registration process; however, recognition of an electronic signature is required to make e-registries equal to other solutions.

- An electronic registry is a prerequisite for an efficient information service.

4. Impact of one-stop-shops depends on the approach. While institutional cooperation and/or a one-stop-shop will reduce the burden on the business, the impact to the efficiency, costs, and quality of registration procedures will differ depending on whether the approach to the one-stop-shop is a postal, physical, or network service or a single-point registration.

Postal services allow businesses to business file the registration dossier in once place, and physical services co-locate staff of the different institutions in one place. In the network service registration materials are electronically distributed to and from the necessary institutions, and in a single-point system, which represents the best practice approach, the registration mandate is delegated to one institution that perfects the registration on behalf of collaborating institutions.

5. Information service must consider public access. Registry frameworks and reforms not including public access to legally binding information do not represent good practice for providing protection of third parties. 


\section{Summary and Key Characteristics of the Reform}

This case study focuses on Ireland's business registration reform process and the creation of one of the world's leading business registration systems ${ }^{1}$ to match the needs of one of Europe's fastest growing economies. ${ }^{2}$

Ireland joined the European Community ${ }^{3}$ (EC) in 1973. During the 1980s, the country went through turbulent times-ineffective government policies in the early 1980s, combined with global economic problems, led to high unemployment, mass emigration, and shrinking foreign investment. The era was marked by political instability and frequent changes of government. In 1987, the government launched a series of economic reforms known as the "Tallaght Strategy." The reforms were supported by the European Union (EU) and helped Ireland enter a period of economic growth known as its "Celtic Tiger" phase. In the 1990s, the Irish economy grew by 5 to 6 percent annually, and eventually surpassed many more established economies in Western Europe. Ireland's rapid economic growth resulted in an increased number of newly registered businesses, and with them, new challenges to Irish institutions.

In the 1990s, although many new businesses were registered, most of them failed to submit annual returns on time, placing doubts on the efficiency of the business registration system (see Table 1). As a consequence, the Companies Registration Office's (CRO's) registry became outdated and faced a continual struggle to assimilate backlogged data. However, the registration problem was more complex. The underpinning legislation, the Companies Act of 1963, had never properly been enforced. In addition, the information stored in the registry was in large measure not legally binding for companies and third parties. The lack of consistency between the company records kept in the registrar and the real company status imposed risks to state institutions, third parties, and business partners.

Table 1: Low compliance rates $1994-1997^{4}$

\begin{tabular}{|l|l|l|l|l|l|}
\hline YEAR & $\begin{array}{l}\text { COMPANIES } \\
\text { DUE TO FILE }\end{array}$ & $\begin{array}{l}\text { FILED } \\
\text { ON TIME }\end{array}$ & $\begin{array}{l}\text { COMPLIANCE } \\
\text { RATE (\%) }\end{array}$ & $\begin{array}{l}\text { FILED AT 31 } \\
\text { DECEMBER }\end{array}$ & $\begin{array}{l}\text { COMPLIANCE } \\
\text { RATE (\%) }\end{array}$ \\
\hline 1994 & 121,282 & 19,442 & $\mathbf{1 6}$ & 47,476 & $\mathbf{3 9}$ \\
1995 & 123,279 & 22,341 & $\mathbf{1 8}$ & 49,061 & $\mathbf{4 0}$
\end{tabular}

1 Ireland is ranked No 7 globally according to the Doing Business 2009 report, available at http://doingbusiness.org/ExploreEconomies/?economyid=93

2 Before the global financial crisis in 2009, which led to a decrease in Ireland's rate of economic growth

${ }^{3}$ The European Community is the first of the three pillars of the European Union (EU) created under the Maastricht Treaty (1992). It is based upon the principle of supranationalism and has its origins in the European Economic Community, the predecessor of the European Union

${ }^{4}$ Source CRO 


\begin{tabular}{|l|l|l|l|l|l|}
1996 & 128,663 & 21,261 & $\mathbf{1 7}$ & 50,259 & $\mathbf{3 9}$ \\
1997 & 136,245 & 17,801 & $\mathbf{1 3}$ & 49,242 & $\mathbf{3 6}$ \\
\hline
\end{tabular}

Table 2: Key Elements and Characteristics of the Reform

\begin{tabular}{|c|c|}
\hline Element & Characteristics \\
\hline Context & $\begin{array}{l}\text { Reform was initiated politically at the } \\
\text { ministerial level and aimed at redressing poor } \\
\text { enterprise compliance with registration } \\
\text { obligations }\end{array}$ \\
\hline Baseline data & $\begin{array}{ll}1997 \text { compliance rate: } & 13 \% \text { (on date) }^{5} \\
\text { CRO stated goal: } & 100 \% \\
\text { (however, without any timeline stated) }\end{array}$ \\
\hline Post-reform performance indicators & 2007 compliance rate: $77 \%$ \\
\hline Scope & $\begin{array}{l}\text { Legal } \\
\text { Passage of Electronic Commerce Act and } \\
\text { Company Law Enforcement Act } \\
\text { Institutional } \\
\text { Establishment of Office of the Director of } \\
\text { Corporate Enforcement } \\
\text { Business Process and E-filing } \\
\text { Introduction of a succession of e-filing systems }\end{array}$ \\
\hline Funding & $\begin{array}{l}\text { Reforms were funded entirely from the CRO's } \\
\text { yearly operational budgets }\end{array}$ \\
\hline Organization & $\begin{array}{l}\text {-Governmental-level oversight } \\
\text {-CRO management drove the process } \\
\text {-Regular consultations with private sector }\end{array}$ \\
\hline Approach and methodology & $\begin{array}{l}\text {-Goal-oriented } \\
\text {-Risk driven }\end{array}$ \\
\hline Monitoring program & $\begin{array}{l}\text {-Establishment of several monitoring and } \\
\text { evaluation committees both within CRO and } \\
\text { the Department of Enterprise, Trade and } \\
\text { Employment (DETE) } \\
\text {-Regular monitoring and evaluation by CRO } \\
\text { management }\end{array}$ \\
\hline
\end{tabular}

\footnotetext{
${ }^{5}$ See Brian O'Hare, CRO, Company Incorporation and Company Compliance Presentation available at http://www.pobail.ie/en/CommunityLocalDevelopmentProgrammes/CohesionProcess/CorporateGoverna nceSeminarSeptember2007/file,8597,en.ppt
} 


\begin{tabular}{|l|l|}
\hline Stakeholder involvement & $\begin{array}{l}\text {-Regular meetings with user committees } \\
\text {-User Acceptance Testing program }\end{array}$ \\
\hline Training & $\begin{array}{l}\text {-Extensive staff training prior to rollout of new } \\
\text { rules, regulations, procedures, and services } \\
\text {-Training program covering legal and } \\
\text { operational issues }\end{array}$ \\
\hline Awareness & $\begin{array}{l}\text { Country-wide information and awareness } \\
\text { program with live demonstrations }\end{array}$ \\
\hline
\end{tabular}

\section{A. Background}

\section{A.1 Legal Framework}

The Companies Act of 1963 and its amendments form the basis of Ireland's Company Law, part of which covers business registration procedures. This act and other statutes pertaining to company registration are predicated on British legal tradition, particularly the U.K. Companies Act of 1948.

The Ireland Companies Act of 1963 requires companies to file an annual return, including financial statements. Registration with the CRO is the ultimate step in the process of incorporation and has a constitutive effect. The CRO issues certificates of incorporation that serve to verify the name and legal form of the company. The original certificate is held by the company itself and copies can be issued by the CRO upon request. A new original certificate will only be issued following changes to the company's name or legal form. In addition, the CRO played a key role in enforcing the filing of annual returns. Still, data formerly registered with the CRO were not legally binding (with the exception of incorporation information) and not "bankable" for third parties. Essentially, records kept by the companies themselves were the only source of legally binding information on legal representation and other matters.

The Irish Companies Act underwent significant changes after Ireland became a member of the EC in 1973, even as the basic precepts of the law governing company registration remained in place.

\section{A.2. Institutional Framework}

The Companies Registration Office in Dublin was established in 1890. Prior to 1963, Ireland's Companies Registration Office was administered by the Revenue Commissioners. ${ }^{6}$ However, after the enactment of the Companies Act 1963, the CRO became part of the Department of Enterprise, Trade and Employment (DETE). ${ }^{7}$

\footnotetext{
${ }^{6}$ Revenue Commissioners is the national tax authority of Ireland.

${ }^{7}$ The Department of Enterprise, Trade and Employment (Irish: An Roinn Fiontar, Trádála agus Fostaíochta) is led by a minister who is assisted by five Ministers of State.
} 
The CRO's main functions provided as state services under the auspices of the DETE are: (i) the incorporation of companies and the registration of business names; (ii) the receipt and registration of post incorporation documents; (iii) the enforcement of the Companies Act in relation to the filing obligations of companies; and, (iv) making companies' information available to the public.

The CRO is also the central repository of public statutory information and business names in Ireland. The CRO hosts the national system electronic database covering the whole territory and jurisdiction of the Republic of Ireland. The CRO's mandate covers the operation of the business registration and information services. The registry's database operates as a stand-alone system. ${ }^{8}$

The $\mathrm{CRO}$ is in charge of the following registries:

- Registry of Companies

- Registry of Mortgages \& Charges (against companies)

- Registry of Business Names

- Registry of Auditors

- Registry of External Companies

- Registry of Limited Partnerships

- Registry of Friendly Societies

- Registry of Disqualified and Restricted Persons

\section{A.3. Business Registration Procedures before the Reform}

The first step of pre-registration requires applicants to be sworn in before a Commissioner of Oath. As a second step, the appropriate forms had to be filed with supplementary documentation depending on the type of registration or notification. It was possible for many forms to be filed electronically, although it was necessary to file pages needing signatures in hard copy. Companies were obliged to submit registration and notification documents to a number of other public institutions besides the CRO, each of which assigned different identification codes. There was no regular exchange of information among public institutions.

\section{B. Reform planning}

\section{B.1. Mandate}

Following the enactment of the Companies Act in 1963, the requirement to file annual documents was not well enforced. In any case, the CRO lacked the capacity to process

\footnotetext{
${ }^{8}$ For more details about CRO, see Annex 1.
} 
the required paperwork if the annual filing requirement had been strictly enforced. There were sporadic attempts in the 1980s and 1990s to address non-compliance, but the issue did not merit real scrutiny until a few high-profile cases focused attention on enforcement of company law. Ireland's dynamic economic growth sharply contrasted with the CRO's poor performance. The problem of the registry's ineffectiveness surfaced repeatedly in the Irish parliament during the 1980s and 1990s, but no legislative measures were taken to tackle the problem.

Finally, in the late 1990s, Ireland's Department of Enterprise, Trade and Employment took an active role and began to provide strong impetus for reform. The mandate for registration reform was driven by both internal CRO processes and an external government-initiated inquiry into the need for and direction of reforms.

In August 1998, the government formed the Working Group on Company Law Compliance and Enforcement to assess the way forward. Roughly three months later, the group presented its findings in a paper called the McDowell report. The report, which echoed a 1997 CRO study's findings about low levels of compliance, recommended the overhaul of the enforcement regime, the penalty regime, and the CRO's returning procedures.

In setting out its reform aims, the CRO stated: "Our goal remains $100 \%$ of companies filing their annual returns on time and our policy of encouragement allied with a rigorous checking process is pushing us in the right direction." More specifically, the CRO's objectives were to improve the compliance rate of the annual return obligations and thereby bring the information in the registry in line with the records kept by companies themselves. In addition to its goal of achieving100 percent compliance, the CRO's overall strategy was to determine the broad direction for reform without setting up specific long-term objectives or plans. Instead, through an inclusive process involving stakeholder consultation and private sector participation, the CRO rolled out a series of e-registration tools, beginning with the CRODisk registration service in 1999. CRODisk, which was userfriendly and technology-driven, served as a starting point for subsequent e-filing systems, the development of which was funded entirely from CRO operational budgets.

The Registrar of Companies took a lead role in the coordination of different reform activities such as chairing the sub-committee tasked with drafting the Enforcement Act, and at the same time serving as a member of the Minister's Monitoring Committee.

\section{B.2. Organization and Monitoring \& Evaluation of Reform}

In January 1998, the Registrar of Companies and the Secretary General of the DETE signed an Autonomy Agreement, which, in conjunction with a Strategic Management Initiative, was intended to: devolve responsibility for services delivery as far as possible; select appropriate performance indicators on which the Registrar would report; improve 
the DETE's performance reviews of associated bodies; and, improve the DETE's capacity for policy formulation.

A seven-person Autonomy Agreement Monitoring Committee ${ }^{9}$ was appointed by the department to monitor implementation of the agreement. The Committee was responsible for reviewing the business plan prior to its submission to the Minister of Enterprise, Trade and Employment; assessing progress in the implementation of the business plan; resolving any difficulties that arose in the operation of the Autonomy Agreement; assessing the Autonomy Agreement's impact on CRO's activities; and, considering the scope and nature of any successor agreement, which would enter into force by July 1, 2001 at the latest.

\section{Figure 1: Organization of Reform Monitoring \& Evaluation}

The CRO also established a general-users committee, an information technology (IT) committee, and an accountants committee comprised of CRO staffers and private-sector representatives. The three committees held quarterly meetings to discuss pertinent aspects of CRO operations.

Internally, the CRO organized a steering group of managers for weekly meetings to discuss progress and to review the work program on a quarterly basis. There were also other sectoral or divisional groupings within the CRO set up to review and offer solutions and assess the uptake of the e-filing service. (See Figure 1.)

\footnotetext{
${ }^{9}$ Referred to as the Monitoring Committee
} 


\section{Reform Dimensions}

The business registration reform in Ireland encompassed four dimensions: legislative reform, institutional reform, business process re-engineering, and the introduction of ICT applications.

\section{C.1. Legislative Reform}

\section{C.1.1. Amendments in Companies Legislation}

The first task of the Companies Law Review Group (CLRG) was to undertake a detailed review and produce recommendations on improving the efficiency of the legislative process. As stated in a recent case study, "The first CLRG report in 2001 sought to consolidate (into a single act) over 100 individual sections of law together with over 300 separate offenses." 10 The government was firmly committed to the consolidation of the law into a single statute in order to facilitate innovation and capacity building.

The most critical outcome of the CLRG report was a reorientation of the law that better reflected the reality of Irish businesses by underscoring the primacy of the private company, limited by shares, as the standard company model for Ireland-a model that reflects 89 percent of Irish companies' legal status. Prior to the reform, the law was geared toward public limited companies and did not adequately provide legal guidance for the treatment of private limited companies. The CLRG's recommendations made private companies limited by shares the benchmark for company law in Ireland. ${ }^{11}$

The underlying objectives behind this reform agenda were to provide Ireland with one of the world's best company law frameworks; to build a degree of efficiency and effectiveness in both the legislation and administration of justice; and to ensure that Ireland would become a reference of choice for dispute resolution by corporate litigants. Additional objectives included the goal of ensuring that the reformed and streamlined companies' code should be effective, easily followed by company directors and shareholders, and a better reflection of how business is conducted in Ireland and in other advanced economies.

The Company Law Review Group recommended a series of improvements across all aspects of Ireland's company law. Many of these recommendations were minor but had a significant impact on the law that emerged. For example, changes such as the

\footnotetext{
${ }^{10}$ ERS (Enterprise Registry Solutions). 2005. "Case Study: The Irish Company Registry." Report prepared for the Business Environment Unit (Small \& Medium Enterprise Department), World Bank Group, Washington D.C. http://advisoryservices.ifc.org/go/docdetails.aspx?mid=52\&mde=bt\&id=611

${ }^{11} \mathrm{ibid}$
} 
elaboration of a single-document constitution governing private company limited by shares (CLS) had a significant impact.

\section{C.1.2. Introduction of Electronic Documents and Electronic Signatures}

In addition to the Companies Act amendments, in 2000, the Electronic Commerce Act was passed, enabling the CRO to develop electronic forms that would be legally recognized. This was the key milestone in triggering the transition from paper forms to eforms. The e-forms were recognized as legally binding documents, opening the paths for ICT applications in the business registration process in Ireland. The introduction of electronic signatures and electronic documents in Ireland not only supported business registration reform but became its critical component. As a result, Ireland developed one of the leading ICT applications for business registration in the world.

\section{C.1.3. New Enforcement Regime, Penalty, and Sanctions System}

In 2001, the government implemented the recommendations of the McDowell Report by passing the Company Law Enforcement Act. The revised enforcement regime came into force following the enactment of the new legislation without any transition period.

The act set forth a new regime for enforcing company compliance. A penalty scheme was created to boost compliance with registration regulations. In addition, the act took into consideration that the government had significantly increased requirements under which companies' accounts could be audited. Under the new law, a company's right of exemption from audit might be forfeited if it files late. This new rule strongly incentivized the timely filing of returns.

The CRO established new procedures for cases in which companies are poor or late filers. Before imposing sanctions, the CRO sends notices to companies before their annual return date, and reminder notices when an annual return date passes without a filing. The CRO sends notices warning of strike-offs or prosecutions where applicable. In addition, the CRO issues a twice-yearly bulletin, "Compliance Matters," to all directors, and undertakes advertising campaigns during peak filing periods.

Among other provisions, the law allowed for the imposition of penalties on reports that were filed late at $€ 100.00$ plus $€ 3.00$ per day up to a maximum of $€ 1,200$ per return. The act also clarified the date on which annual returns are due, because under the old regime, some companies claimed their uncertainty about the due date kept them from 
filing on time. However, a waiver was provided for not-for-profit companies engaged in charitable work or community welfare in cases of force majeure. ${ }^{12}$

In addition, the new Company Law Enforcement Act provided for new rules on prosecution, strike-off and court injunction:

Prosecution: If companies do not respond to the notices, the CRO can prosecute companies and their directors through the District Court for failing to file annual returns on time. A company is selected for prosecution based on its delinquency in filing. The penalty can reach $€ 1,900$ for each offense, and a director with three convictions can be disqualified from directorship and involvement with any company for a period of time.

Strike-off: The CRO can also act to strike a company from the registry after it fails to file at all. This process involves stepped procedures and various notices before the strike-off occurs. Companies that have been removed from the registry lose the privilege of limited liability and their assets are vested by the Minister for Finance. In addition, the Director of Corporate Enforcement, $\mathrm{CRO}$ is empowered to seek the disqualification or restriction of company directors. However, these companies can be restored by administrative order or by the court.

Court Injunction: In some cases, the registrar is empowered to seek an order from the High Court directing a company to file outstanding returns. This action follows the failure of a company to file in response to a specific warning notice. The Registrar may also seek to recover its costs from a company in the event that proceedings are launched. Nevertheless, the court injunction has been used sparingly but successfully. ${ }^{13}$

\section{C.1.4. ICT Applications in the Penalty and Sanctions System}

The CRO's previous IT systems allowed for the creation of lists of defaulting companies, but were limited in assessing and configuring data on defaulting companies. This created operational inefficiencies that prevented CRO staff from obtaining reliable information on defaulting companies and seeking enforcement. In 2004, enforcement systems were combined into a framework known as the "Integrated Enforcement Environment" (IEE). The IEE enabled the CRO to create and manage multiple configurations and options with respect to defaulting corporations.

\section{C.2. Institutional Framework after the Reform}

\footnotetext{
12 "Force majeure" means an unforeseeable event or condition which rendered a party's performance impossible, and which is beyond the party's control, such as war, civil unrest, riots, changes in law, earthquake, hurricanes, floods, tornadoes, etc.

${ }^{13}$ See Brian O'Hare, CRO, Company Incorporation and Company Compliance Presentation available at http://www.pobail.ie/en/CommunityLocalDevelopmentProgrammes/CohesionProcess/CorporateGoverna nceSeminarSeptember2007/file,8597,en.ppt
} 
After the reform, the CRO remained in charge of all the old registries and continued to perform its main functions, but with new responsibilities in the area of enforcement, prosecution, and striking-off companies from the registry of companies. The CRO undertakes three tasks: submission processing, which entails receipt and processing of incorporation and post-incorporation documentation and which facilitates the updating of the registry; enforcement of the Companies Act with respect to corporations' filing obligations; and inquiry processing, which involves the provision, distribution, and publication of registered information for the public. In 2001, the DETE established an Office of the Director of Corporate Enforcement to focus solely on issues of compliance with respect to company registration.

Today the CRO's operations are based at two locations: the Dublin headquarters and a Carlow branch office. The CRO relocated some functions to Carlow in summer 2007 as part of the government's decentralization program. As of April 1, 2008, the CRO had 147 staff members, 117 based in Dublin and 30 in Carlow. The Carlow office receives and scans the majority of statutory documents and processes annual returns. The remaining documents are received and processed in Dublin. Other than annual returns, documents received and scanned in Carlow are verified in Dublin via an imaging system.

Figure 2: Structure and Geographic Location of CRO's Offices after the Reform 


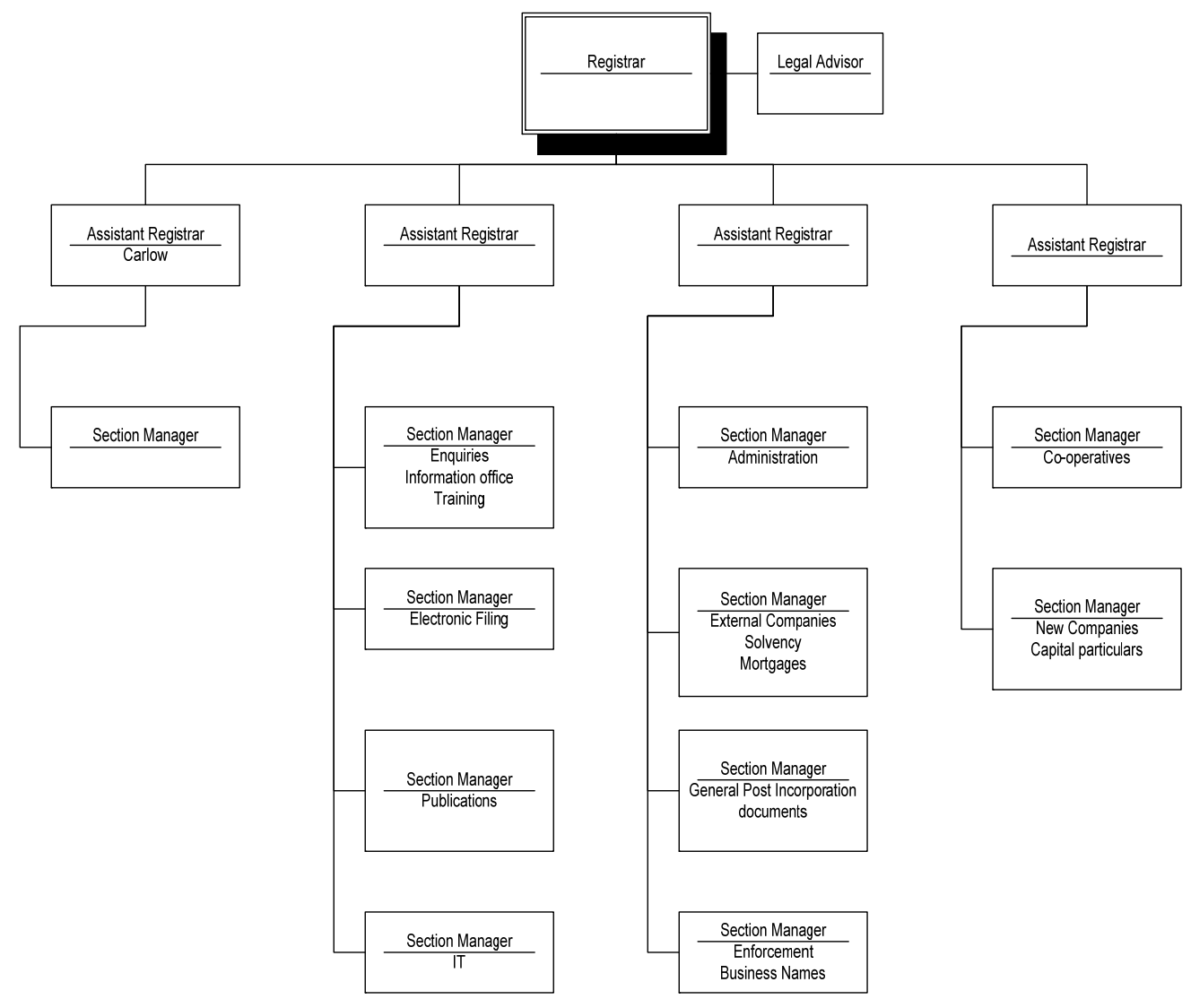

The CRO has introduced a range of e-filing services covering different forms, although signed pages must still be filed in hard copy. The availability of e-filing options has substantially improved the timely submission of annual returns. Registry information and documents are accessible via the Internet. The CRO also operates a telephone service that provides information to the public.

\section{C.3. Business Registration Process and Procedures after the Reform}

A business is registered through the Registration Service System (RSS). The RSS is a system of applications, services, and data repositories (image and text) that has supported the CRO's daily processes and services since 1998. The RSS operates in the following way:

To register a business, a person needs to file Form A1 which requires information on: company name; company representative; secretary and directors; signatories to the incorporation documents; authorized and issued share capital and stamp payments; a compliance statement; description of activity; Nomenclature Generale des Activités Economiques (NACE) code; location of the registered office, the central administration and main company activities. Before filing with the registry, Form 1 needs to be verified 
and the compliance statement must be sworn before a Commissioner of Oaths: a representative (director, secretary, or solicitor) engaged in the company's formation must confirm in writing (in the statutory incorporation form) that the company has complied with all relevant provisions of the Irish Companies Act and declare that the company will carry on its activity in the state where it has been incorporated. The signing of the form must be executed before a Commissioner of Oath who can attest the swearing. To complete the filing, Form A1 needs to be supplemented with the attached constitution documents: memorandum of incorporation, including signatures; complete list and specific information on each shareholder, and the articles of association. The paper dossier of company information needs to be sealed before it is filed. Upon receipt of the company dossier by the CRO, all documents in hard copy are scanned and the registration process is undertaken using scanned images. Hard copies are subsequently archived. At this stage, there is neither cross-checking nor validation of filed information with any other registries or authorities.

Registration at the CRO may be filed in one of three ways (see Figure 3):

1. Ordinary registration, by submitting a hard-copy registration dossier in which the incorporation documents are not in a format pre-approved by the CRO. Under this method, the registration process may require two to three weeks because all submitted documentation must be scrutinized in detail;

2. Fe Phrainn registration, ${ }^{14}$ under which incorporation documents can be filed as hard copies in a pre-approved Registry format. This is a paper-based system in which draft memorandum and articles of incorporation are submitted for approval, printed by applicant. The Fe Phrainn paper-based registration requires up to 10 days;

3. CRODisk registration, which is the electronic version of Fe Phrainn, with no paper filing.

Figure 3: The Three Ways to Register Company in Ireland

\footnotetext{
${ }^{14}$ Fe Phrainn registration is a streamlined paper-based system for business registration in Ireland that requires membership.
} 


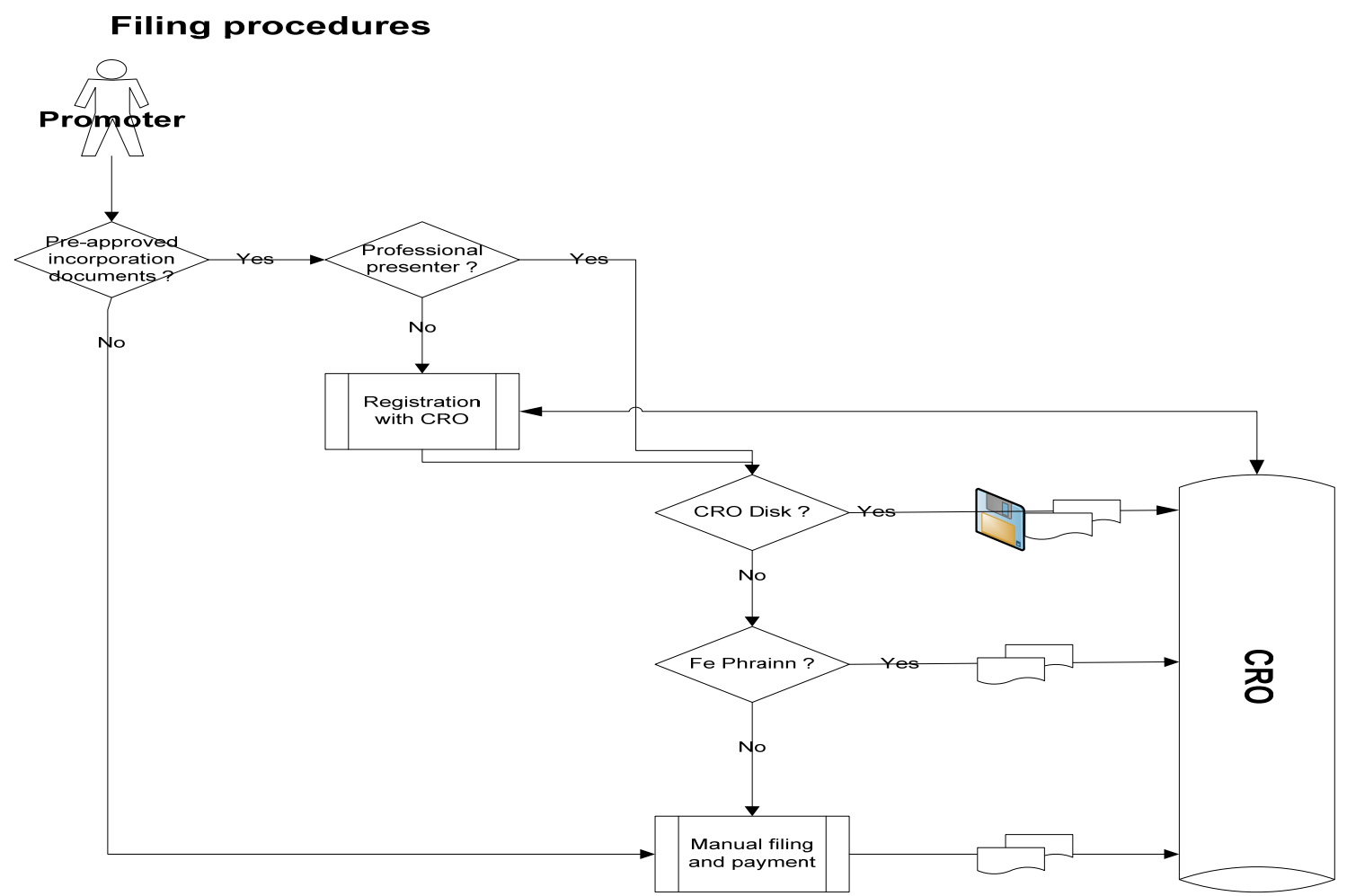

To register for taxes and social insurance with the revenue commissioners, companies must file Form TR2. The process can be completed within one day. However, VAT registration requires an additional five to ten working days.

Companies are obliged to notify the CRO of any changes or amendments to previously registered information. The form a company must use depends on the actual amendment being registered, although e-filing services cover most forms. However, signature pages must, as previously stated, be signed and filed in hard copy. When a discrepancy is detected between the company information held by the CRO and the company's annual return, the CRO will notify the company about updating its obligations and ask that it file a specific form covering the discrepancy.

\section{C.4. E-filing Services after the Reform}

In September 1998, the CRO rolled out a new IT system, which included an e-filing application for the registration of new companies; registration of mortgages; and filing of annual returns. Since then, the CRO has rolled out a number of e-filing systems. ${ }^{15}$ Electronic filing was intended to work in conjunction with existing processes, to offer clients the opportunity to choose between hard-copy or e-filing, and to avoid the need for a transition period.

\footnotetext{
${ }^{15}$ For a full list of e-filing systems and requirements, see Annex 3.
} 
When a company electronically files its annual return form, it is deemed received once the form has been submitted online. The relevant hard copies of paperwork must reach the CRO's premises within 28 days, effectively providing companies a month in which to prepare accounts and complete the signature of forms.

\section{C.5. Funding, Costs, and Donor Support}

The CRO's financial arrangements and funding did not undergo any changes to support the reform. All revenue and fees accrued from the registry's services go to the treasury and all operational costs are covered by the state budget.

All reform costs were funded from the general operation budget without specific allocations for work, services, or procurements (see Table 3).

Table 3: Costs for Development and Introduction of Electronic Filing Services (1999-2007) ${ }^{16}$

\begin{tabular}{|l|l|r|r|}
\hline \multicolumn{2}{|l|}{ Amounts as Euro } & \multicolumn{1}{c|}{ Total } \\
\hline ICT development projects & & $\mathbf{2 , 5 4 3 , 6 7 9}$ \\
\hline & -procurements of services & $2,011,177$ & \\
\hline & -project management & 532,502 & \\
\hline Management and Promotion & & $\mathbf{6 2 5 , 8 8 0}$ \\
\hline & -management & 238,075 & \\
\hline & -promotion & 387,805 & \\
\hline Procurements & & & $\mathbf{6 4 1 , 2 6 8}$ \\
\hline & -softw are & 342,728 & \\
\hline & -HW/technical platform & 40,000 & \\
\hline & -SW licenses & 258,540 & \\
\hline Total & & & $\mathbf{3 , 8 1 0 , 8 2 7}$ \\
\hline
\end{tabular}

\section{C.6. Information Campaign}

The CRO conducted a countrywide information and public-awareness campaign, giving demonstrations and presentations about its services. The campaign included roadshows and advertising, marketing, and media campaigns. The general goal of the campaign was to introduce the new annual returns filing system, the new enforcement rules, and the reformed system. During the campaign, the CRO witnessed the on-the-ground challenges in changing a culture of non-compliance with the old system among some companies to one of full compliance with the new system. ${ }^{17}$

\footnotetext{
${ }^{16}$ Source CRO

${ }^{17}$ ERS (Enterprise Registry Solutions). 2005. "Case Study: The Irish Company Registry." Report prepared for the Business Environment Unit (Small \& Medium Enterprise Department), World Bank Group, Washington

D.C. http://advisoryservices.ifc.org/go/docdetails.aspx?mid=52\&mde=bt\&id=611
} 


\section{Conclusion and Results achieved through Reform}

\section{D.1. Impact and Performance Indicators}

By the end of 2000, roughly 40 percent of Irish enterprises had begun to file timely returns. As the enforcement-regime initiatives, such as strike-off actions and the establishment of the Office of Director of Corporate Enforcement, came into force, compliance improved even further. The implementation of new e-filing services resulted in filing rates of nearly 80 percent by the end of 2007. However, improved e-filing of initial registrations has not greatly affected the volume of new company registrations, which remained relatively stable over the 1997-2007 period.

Table 4: Reform Measures and Corresponding Improvements in Compliance ${ }^{18}$

\begin{tabular}{|c|c|c|c|c|c|c|}
\cline { 2 - 7 } & Annual Return & Penalties & e-filing & Implemented & No of & Population \\
\hline & On date & Mill. If & services & regime reforms & 19023 & 164958 \\
\hline 1997 & $13 \%$ & & & & 20874 & 178773 \\
\hline 1998 & $19 \%$ & & & & 18604 & 161384 \\
\hline 1999 & $25 \%$ & & CRODisk & Office of the Director of Corporate Enforcement & 18840 & 137654 \\
\hline 2000 & $39 \%$ & & & & 14186 & 146331 \\
\hline 2001 & $44 \%$ & 1,8 & & Company Law Enforcement Act & 13735 & 154242 \\
\hline 2002 & $63 \%$ & 12,5 & Jetform & Electronic Commerce Act & 14264 & 148303 \\
\hline 2003 & $67 \%$ & 27,8 & FINER & & 15592 & 157502 \\
\hline 2004 & $70 \%$ & 18,2 & XML & Integrated Enforment Environment & 17234 & 160707 \\
\hline 2005 & $73 \%$ & 21,4 & & & 19190 & 170719 \\
\hline 2006 & $75 \%$ & 20,7 & CORE & & 18704 & 180891 \\
\hline 2007 & $77 \%$ & 17,9 & & & & \\
\hline
\end{tabular}

\section{2. Conclusion}

Between 1998 and 2007, Ireland's corporate registration framework underwent dramatic and wide-ranging reform, encompassing the passage of new legislation, the creation of a new management directorate, and the use of information campaigns and iterative developments in its e-filing systems. The reform achieved significant results and put in place a framework that allows both electronic and paper filing.

The reform of the business registration system in Ireland started from the annual returns filings, but resulted in a broader set of changes, which eventually streamlined more procedures than envisaged.

Among the most notable features of the reform were the new enforcement regime and the application of innovative ICT solutions that streamlined the business registration

\footnotetext{
${ }^{18}$ Source CRO
} 
process, and made it available online, backed by a fully computerized and reliable enforcement system. Other important features of the reform were the new monitoring and project-reporting mechanisms and the open ended, risk-oriented approach the CRO took to overhaul the institutional and operational frameworks for registration.

The Ireland case is unique in the manner in which it was instigated: the reform was technically triggered by the low rate of annual returns filings, but resulted in broader reforms involving legislative, institutional, and operational restructuring. In addition, the reforms were shaped by the application of innovative ICT solutions, helping Ireland establish its business registration system as one of the world's most advanced.

\section{Annex 1: Key CRO personnel}

Paul Farrell, Registrar of Companies

E-mail: paul_farrell@entemp.ie

Claudine Forrest, Electronic Filing Manager 
E-mail: claudine_forrest@entemp.ie

Robert McLean, Deputy Registrar

E-mail: robert_mclean@entemp.ie

Pat Daly, Deputy Registrar

E-mail: pat_daly@entemp.ie

\section{CRO contacts:}

Office: Parnell House, 14 Parnell Square, Dublin, Ireland

Phone: +35318045300

Fax: +35318045222

\section{Consultancy providers:}

John Murray, IT service provider, Company: Enterprise Registry Solutions Ltd.

E-mail:jmm@ersl.ie

Phone: +353871201877

Elaine Daly, consultancy manager, Company: Grant Thornton

Home page: www.grantthornton.ie

E-mail: elaine.daly@grantthornton.ie

Phone: +35316805805

\section{Professional service providers:}

Salvador Nash, Director, Corporate Legal Advisory Services

Company: KPMG

Home page: www.kpmg.ie

E-mail: salvador.nash@kpmg.ie

Phone: +35314101000

David Lydon, partner

Company: Mccann FitzGerald, law firm

Home page: www.mccannfitzgerald.ie

E-mail: david.lydon@mccannfitzgerald.ie

Phone: +35318290000

\section{Annex 2: Reform Workflow}




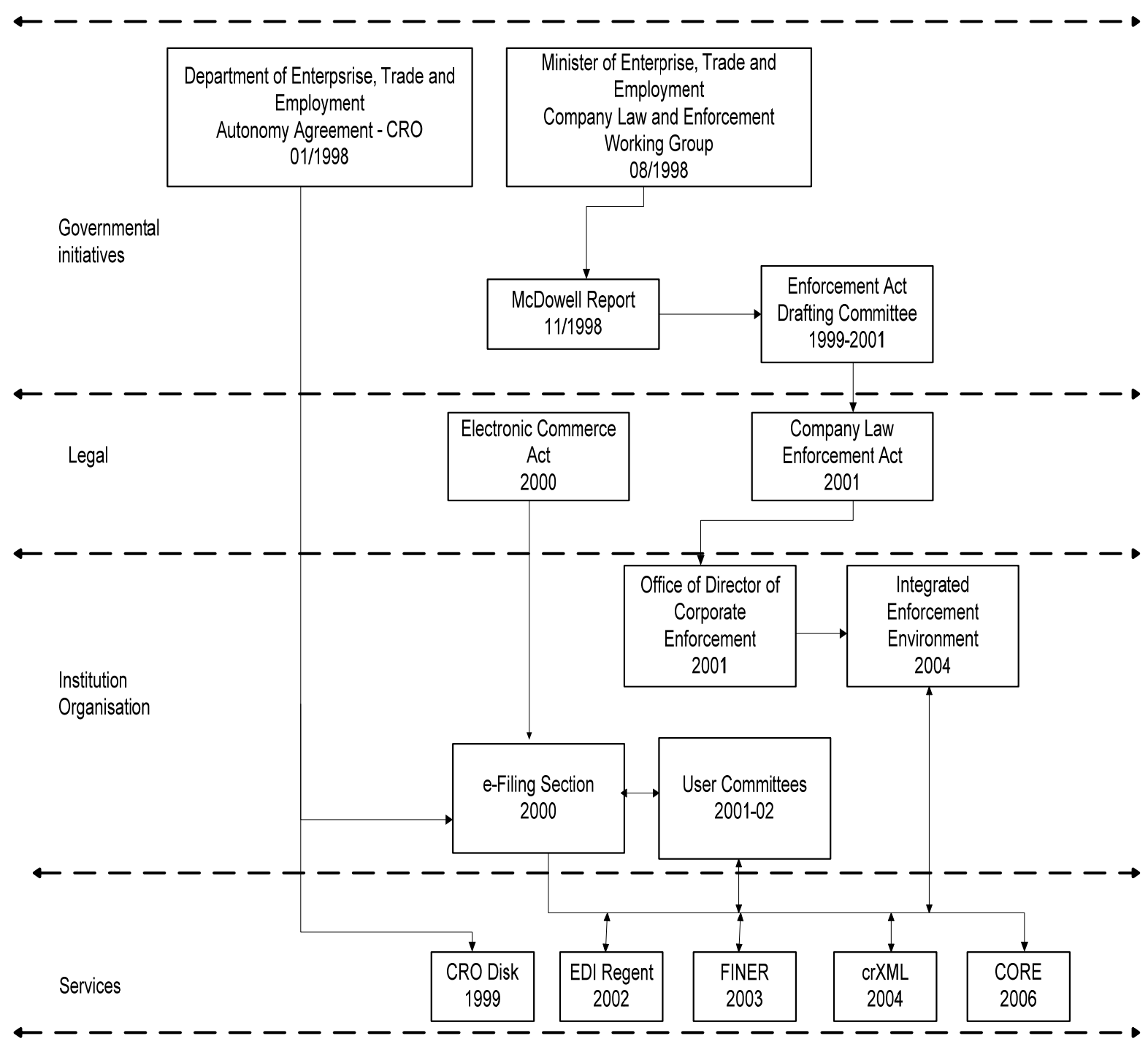

\section{Annex 3: CRO's current online information services}




\begin{tabular}{|c|c|}
\hline $\begin{array}{l}\text { Public Web Search Site } \\
\text { www.cro.ie }\end{array}$ & $\begin{array}{l}\text { Allows customers to search for registered } \\
\text { companies and to order company printouts and } \\
\text { document images. Once paid for (account or credit } \\
\text { card), these are emailed to the customer. Customers } \\
\text { can check the status of their orders at any time and } \\
\text { re-submit them for emailing in case of error. }\end{array}$ \\
\hline CRODETE Web Search Site & $\begin{array}{l}\text { Similar to the Web Search but available only to DETE } \\
\text { staffers. Ordering is free. }\end{array}$ \\
\hline Bulk Data Services & $\begin{array}{l}\text { Third-party information providers can buy data in } \\
\text { bulk by paying an annual fee. Company data is } \\
\text { available in text form in a specified data format on a } \\
\text { daily and weekly basis. Full dumps are done on a } \\
\text { weekly basis and partial updates every day. } \\
\text { Currently partial dumps are made available on the } \\
\text { web site and full dumps are delivered on tape. } \\
\text { Document Image files are output to a third-party } \\
\text { hosted FTP site on a daily basis along with an index } \\
\text { file. Bulk data customers can download them from } \\
\text { there. (Note: Some customers still get images on CD } \\
\text { but this is to be phased out as it involves operator } \\
\text { intervention.) }\end{array}$ \\
\hline Web Service & $\begin{array}{l}\text { A Web Service (HTTP post), also available to bulk } \\
\text { customers, allows searches and the requesting of } \\
\text { company printouts and images directly from CRO } \\
\text { systems. }\end{array}$ \\
\hline
\end{tabular}

\section{Annex 4: CRO's e-filing services, past and present}

\begin{tabular}{|l|l|l|l|l|l|}
\hline $\begin{array}{l}\text { ELECTRONIC } \\
\text { FILING SERVICES }\end{array}$ & DESCRIPTION & APPLICATION & PLATFORM & YEAR & FORMS \\
\hline FINER & CRO's online & FINER (SUSe) & Java/XML/XSL/RMI & 2002 & B1, B2, \\
\hline
\end{tabular}


Ireland Business Registration Reform

\begin{tabular}{|c|c|c|c|c|c|}
\hline & $\begin{array}{l}\text { form-completion } \\
\text { service that is } \\
\text { open to the } \\
\text { public use. }\end{array}$ & & $\begin{array}{l}\text { application running } \\
\text { on Apache/Tomcat }\end{array}$ & & $\begin{array}{l}\text { B10,B3, } \\
\text { F4, } \\
\text { RBN2, } \\
\text { RBN2A, } \\
\text { RBN2B, } \\
\text { B77, } \\
\text { B69, } \\
\text { RBN1, } \\
\text { RBN1A, } \\
\text { RBN1B, } \\
\text { M1, } \\
\text { M2, } \\
\text { G1, G2, } \\
\text { B73, } \\
\text { F12 }\end{array}$ \\
\hline $\begin{array}{l}\text { PRESENTER } \\
\text { PORTAL (CORE) }\end{array}$ & $\begin{array}{l}\text { Allows } \\
\text { presenters } \\
\text { (company } \\
\text { representatives) } \\
\text { to watch their } \\
\text { companies, } \\
\text { monitor activity } \\
\text { and to review } \\
\text { accounts online. }\end{array}$ & $\begin{array}{l}\text { CORE (Win } \\
2003 \text { Server) }\end{array}$ & $\begin{array}{l}\text { Java/JSP } \\
\text { application running } \\
\text { on Tomcat } 5.0\end{array}$ & 2006 & $\begin{array}{l}\text { As } \\
\text { above }\end{array}$ \\
\hline $\begin{array}{ll}\text { CRXML } & \text { WEB } \\
\text { SERVICE } & \end{array}$ & $\begin{array}{l}\text { CRO's online } \\
\text { electronic filing } \\
\text { service, which } \\
\text { permits third- } \\
\text { party } \\
\text { applications to } \\
\text { submit electronic } \\
\text { forms using the } \\
\text { crXML message } \\
\text { standard. }\end{array}$ & CRXML (SuSe) & $\begin{array}{l}\text { Java/XML/XSL/RMI } \\
\text { application running } \\
\text { on Tomcat } 5.0\end{array}$ & 2004 & $\begin{array}{l}\text { B2 and } \\
\text { B10 }\end{array}$ \\
\hline $\begin{array}{l}\text { RSS INTERFACE } \\
\text { SERVER }\end{array}$ & $\begin{array}{l}\text { A server that acts } \\
\text { as an } \\
\text { intermediary } \\
\text { between the } \\
\text { FINER and crXML } \\
\text { servers and the } \\
\text { RSS database. }\end{array}$ & $\begin{array}{l}\text { FINER-PROD } \\
\text { (SuSe) }\end{array}$ & $\begin{array}{l}\text { J2EE/XML/XSL } \\
\text { application running } \\
\text { on JBoss. }\end{array}$ & & \\
\hline
\end{tabular}




\begin{tabular}{|c|c|c|c|c|c|}
\hline & $\begin{array}{l}\text { RSS IS extracts } \\
\text { data from crXML } \\
\text { messages and } \\
\text { inserts it into } \\
\text { corresponding } \\
\text { database tables } \\
\text { for use by other } \\
\text { applications. }\end{array}$ & & & & \\
\hline $\begin{array}{l}\text { B1 EDI WEB } \\
\text { SERVICE }\end{array}$ & 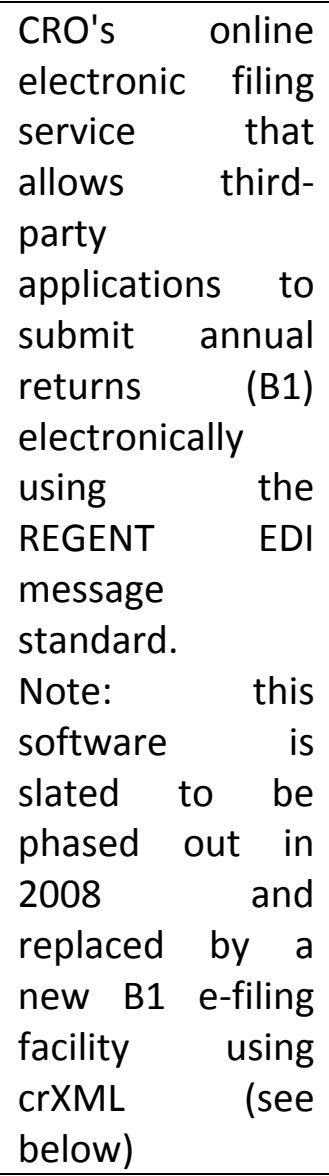 & $\begin{array}{l}\text { B1 (Win } 2000 \\
\text { Server) }\end{array}$ & $\begin{array}{l}\text { ASP/ VB } 6.0 \\
\text { IIS } 6.0\end{array}$ & 2002 & B1 \\
\hline $\begin{array}{ll}\text { B1 } & \text { EDI } \\
\text { PROCESSOR } & \end{array}$ & $\begin{array}{l}\text { Processing } \\
\text { engine that polls } \\
\text { the database for } \\
\text { annual returns } \\
\text { electronically } \\
\text { filed through the } \\
\text { B1 SERVER, } \\
\text { validates and } \\
\text { extracts the data, } \\
\text { and inserts them } \\
\text { into the RSS } \\
\text { database for }\end{array}$ & $\begin{array}{l}\text { CROB1 (Win } \\
2000 \text { Server) }\end{array}$ & VB 6.0 / XML & & \\
\hline
\end{tabular}




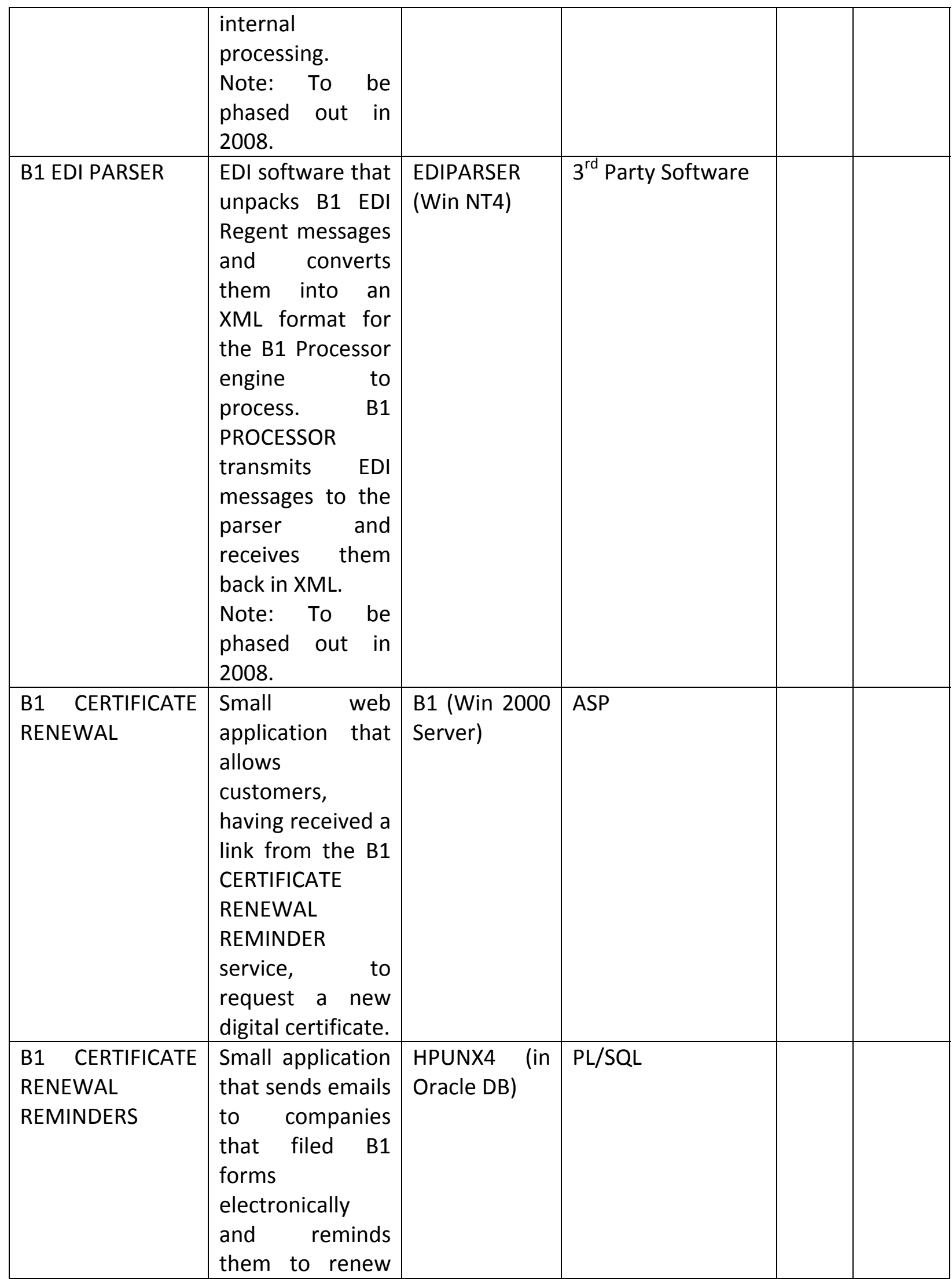


Ireland Business Registration Reform

\begin{tabular}{|c|c|c|c|c|c|}
\hline & $\begin{array}{l}\text { their digital } \\
\text { certificates } \\
\text { before the expiry } \\
\text { date. }\end{array}$ & & & & \\
\hline CRODISK & $\begin{array}{l}\text { CRO's original } \\
\text { electronic filing } \\
\text { software that } \\
\text { allows } \\
\text { presenters to } \\
\text { maintain a } \\
\text { database of } \\
\text { companies and } \\
\text { directors and to } \\
\text { submit form data } \\
\text { on disk along } \\
\text { with signed } \\
\text { paper copies. } \\
\text { Mostly used to } \\
\text { incorporate } \\
\text { companies } \\
\text { although can } \\
\text { handle some } \\
\text { post- } \\
\text { incorporation } \\
\text { documents. }\end{array}$ & $\begin{array}{l}\text { External } \\
\text { Customer PCs } \\
\text { - Win } 2000 \\
\text { and upwards } \\
\text { certified }\end{array}$ & MS Access 2000 & 1999 & $\begin{array}{l}\text { A1, B2, } \\
\text { B10 }\end{array}$ \\
\hline
\end{tabular}

